INTERNATIONAL DESIGN CONFERENCE - DESIGN 2018

https://doi.org/10.21278/idc.2018.0233

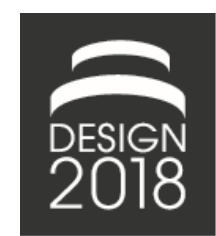

\title{
DESIGN PRINCIPLES FOR CREATIVE SPACES
}

\author{
K. Thoring, R. M. Mueller, P. Desmet and P. Badke-Schaub
}

\begin{abstract}
Work and study environments that facilitate creative design processes - so called creative spaces - have gained an increased interest in the past years. This paper contributes to this emerging field by providing a set of guidelines for creating such environments. We developed a set of 49 abstracted design principles (patterns) that are empirically developed, embedded in the broader system of creative spaces, and supplemented by examples. The suggested principles provide concrete, yet adaptable, guidelines for designers, educators, and spatial planners who want to redesign their creative environments.
\end{abstract}

Keywords: creative space, architectural design, design guidelines, design science, design theory

\section{Introduction}

Designing a creative work or study environment involves several aspects, such as ergonomics, comfort, technical infrastructure, or personal taste. However, those design decisions are often based on ad-hoc decisions and rather unsystematic. Although there exists a substantial amount of literature with examples of creative spaces or even suggestions for design solutions, a systematic and comprehensive set of design guidelines with related propositions about the potential impact of these designs, is missing. The development of such design principles is the concern of the work presented in this paper. This endeavour bears resemblance to the seminal book "A Pattern Language" (Alexander et al., 1977) but addresses the peculiar area of creative environments in both design education and practice. Alexander et al.'s Pattern Language presents a total of 253 abstracted guidelines (patterns) for any area related to architecture and town planning that can be adapted to individual building or construction projects. A few of these patterns address workspaces (patterns 146 to 153), but without any focus on creative spaces. We build on Alexander's concept and present a set of 49 design principles that can also be considered 'patterns' for creative spaces. We regard a space as 'creative' when it facilitates activities in a design education or design practice environment. This includes but is not limited to the facilitation of creativity. The term 'creative space' spans from a single piece of furniture to the interior design and layout of rooms; and from architectural structures to the location within neighbourhood and city (Figure 1).

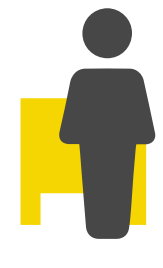

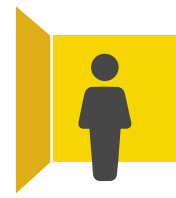

INTERIOR

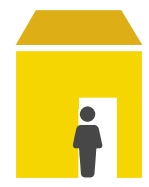

ARCHITECTURE

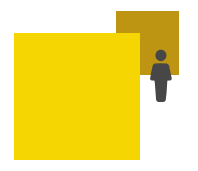

NEIGHBOURHOOD

Figure 1. System of creative spaces 
We address creative spaces in different contexts: in educational institutions as well as in corporate environments, and also in affiliated or external facilities like incubators or maker spaces. The developed design principles are abstract enough to be adapted to all of these contexts.

Each of the developed principles provides a description of the problem context, examples, and links to supporting literature. This paper outlines the full list of developed principles and describes a few selected principles in more detail. While this list does not claim to be exhaustive, we argue that it covers a comprehensive view into the entire range of relevant spaces within design education and practice and provides concrete, yet adaptable, guidelines for designers, design educators, and spatial planners who want to redesign their creative environments.

\section{Related literature}

The large number of recently published 'coffee table books' on the topic of creative spaces in both design educational and practitioner's contexts indicates the increased public interest in this field (e.g. Stewart, 2004; Groves et al., 2010; Dudek, 2012; Ehmann et al., 2012; Borges et al., 2013; Mirchandani, 2015; Georgi and McNamara, 2016). However, these publications do not provide any theoretical underpinning or explanations about possible reasons why the spaces are designed as they are, or how one should design a creative space by oneself.

To further investigate this topic, we conducted a systematic literature search within the Scopus database with both keywords 'creative learning spaces' and 'creative work or office spaces'. For both search steps, possible combinations with synonyms were also considered (e.g. space vs. environment, creative vs. innovative, office vs. work). The resulting 242 sources were analysed based on their abstract and full-text and expanded by cross-citation analysis. This procedure resulted in a total of 44 sources identified as relevant. These 44 sources were clustered and grouped according to their contribution (case studies, classifications, literature reviews, theories, experiments, and design guidelines). Only five sources presented guidelines for developing creative spaces. In the following we only discuss those because this is also the concern of our paper.

Snead and Wycoff (1999) suggested several instructions how a space should be designed in order to facilitate collaboration and teamwork. They provided some abstract spatial configurations that should support the identified categories Interaction, Visual Thinking, Beauty, Fun, Abundance, and Tools. However, they provided no evidence or theoretical underpinning why the suggested spatial settings would result in improved collaboration. Moreover, space types other than collaboration spaces were disregarded. Doorley and Witthoft (2012) presented a collection of 63 instructions for designing collaboration furniture or interior design elements. These detailed blueprints include drawings, material suggestions and even names of suppliers. Also, each blueprint provides some links to other blueprints that might be of relevance in that context, which resembles the Pattern Language by Alexander et al. (1977). However, the presented blueprints are not embedded into a broader system of creative spaces, nor do they provide explanations how they are supposed to facilitate creative work processes. Williams (2013) developed a linguistic grammar of creative workplaces that also resembles Alexander et al.'s Pattern Language approach (1977). In a semiotic sentence structure (following an if - then structure known from e.g. computer science), the condition of a specific intended behaviour (syntax) would result in a peculiar combination of place, properties, and affordances (lexis). The main portion of Williams' work is dedicated to developing and testing the grammar's elements and to providing codes for those elements' characteristics. The results are instructions how one could construct spatial rules with the provided grammar elements (the 'act of writing sentences') on their own. To that effect, she developed the grammar but did not develop the language or patterns that would be needed to design creative spaces by oneself. Paoli et al. (2017) analysed images of creative spaces found in the Internet and categorized these according to five themes: (1) Home, (2) Sports and Play, (3) Technology, (4) Nature, and (5) Symbolism. For each theme they present a summary of certain design characteristics that can be regarded as design guidelines. Ceylan et al. (2008) measured the perception of different office designs regarding creativity. They presented photographs of 25 different offices to 60 managers from a large manufacturing company. Based on these managers' self-reports, preliminary guidelines for creative spaces were developed. The identified physical characteristics that would support creative processes include (1) low complexity, (2) bright colours, (3) cool colours, (4) presence of plants, (5) presence of windows, and (6) presence of computers. 
The related literature reveals that so far there exists no comprehensive overview of patterns for creative spaces that is systematically developed, supported by literature, and supplemented by exemplary spatial instantiations. In the following we present our attempt to develop such a 'pattern language of creative spaces'. We decided not to use the grammar of Williams (2013) as the foundation for developing our patterns, because Williams is focusing on creative behaviour in general office settings, while we consider creative spaces as environments specific for design education and practice. Hence, we need more detail for some (design-specific) aspects, and therefore we chose to rely on our own empirical data that was collected in design educational and design practice contexts.

\section{Methodology}

\subsection{Theory construction}

In this paper we present the groundwork of a 'pattern language' about how to design creative work and study environments, which can be regarded a preliminary design theory. According to Popper (1934), a theory is an abstracted model of the reality. Building on that, Gregor (2006) differentiated between five types of theories:

1. Theories for analysing only describe and classify the reality, e.g. as a typology (what is?).

2. Theories for explanation attempt to provide explanations for specific incidents (what is, how, why, when, and where?).

3. Theories for prediction provide predictions but without causal explanations (what is and what will be?).

4. Theories for explanation and prediction provide predictions as well as testable propositions and causal explanations (what is, how, why, when, where, and what will be?).

5. Theories for design and action provide explicit prescriptions for constructing an artefact (how to do something?).

The current paper constitutes a type 5 theory (Gregor and Jones, 2007) because it aims to provide design principles, that is, how to design creative work and study environments.

\subsection{Previous work}

Based on a qualitative user study with cultural probes (Gaver et al., 1999) in both an educational design thinking and a design practitioner's environment, we developed a typology of creative spaces. We identified five 'space types' that are necessary for creative activities. Orthogonal to the space type, a 'spatial quality' refers to a space's capacity to facilitate a specific purpose. Figure 2 outlines the characteristics of space types and qualities in more detail. This typology describes, in our view, the entire system of creative spaces in design education and practice. All relevant spaces for any creative activity that were identified with our previous studies were represented by the five suggested space types, and also the five defined qualities covered all identified functions that could be addressed within a particular space. Hence, we use this typology as the basis for the development of design principles for creative spaces. A detailed description of those previous studies can be found in Thoring et al. (in press) and Thoring et al., (2012).

\subsection{Development of spatial design principles}

The development of the 49 design principles was achieved according to the following seven steps:

1. Requirements matrix for creative spaces. Based on the typology of creative spaces (introduced in the previous section, Figure 2), we developed spatial criteria for each intersection of spaces types and spatial qualities. Table 1 illustrates those relations and outlines the possible criteria in an abstracted manner. The resulting requirements matrix guided our development process of design principles for creative spaces.

2. Expert interviews. We conducted semi-structured interviews with eight experts for creative spaces from different disciplines (design education, design practice, architecture, interior architecture, and furniture manufacturing), whose professional experiences ranged from 10 to 30 years. The eight interviews totaled 9.7 hours of audio data - an average of 72 minutes per interview. We transcribed and imported the interviews into ATLAS.ti for further analysis. The analysis was conducted according to a code-structure based on the typology of creative spaces 
outlined in Figure 2. That way, any mentioned insights (positive or negative) regarding space types and spatial qualities could be identified. (Details about the complete interview analysis process can be found in Thoring et al. (2017)).

3. Case studies in design institutions. We analysed 16 innovation and design institutions from education and practice in order to look for real-life examples of creative spaces. Those visited institutions were: IDEO Munich, Steelcase Learning and Innovation Center Munich, Darkhorse Innovation Berlin, Launchlabs Berlin, MHP Porsche Digital Lab Berlin, Parsons School of Design New York, TU Delft, Dessau School of Design, Design Academy Berlin, PolyU Hong Kong, ESAD Porto, SAIC Chicago, HPI School of Design Thinking Potsdam, Detmold School of Architecture, Umeå School of Architecture, and Central Saint Martins College London. In these case studies we focused on direct observations and artefacts (according to Yin, 2003) to identify peculiar spatial configurations. Those environments were photographed and categorized according to the typology of creative spaces outlined in Figure 2.

4. Evidence-based mapping. The empirical evidences found in interview quotes and spatial examples from the 16 case studies (steps 2 and 3) were mapped to the previously defined requirements matrix outlined in Table 1.

5. Framework-based inquiry. Vice-versa, we identified those criteria where no solution was found through our interviews and case studies (that is, any remaining empty cells of the criteria matrix). For those incidents we searched for published case studies with photographs from existing creative spaces (from the 'coffee table books' outlined in Section 2).

6. Search for related literature. Finally, we searched related literature for any existing studies for relevant additional insights to be included in the design principles.

7. Principle formation. All collected insights were assembled and transformed into 49 design principles.

\section{SPACE TYPE}
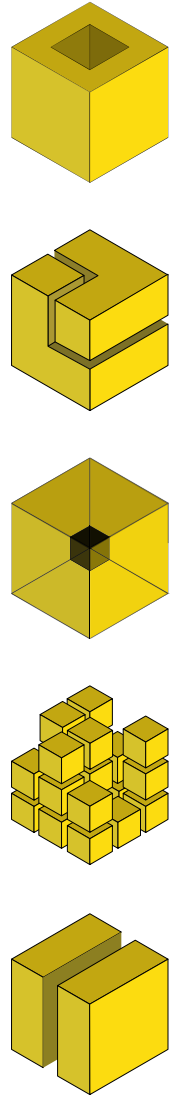

1. PERSONAL SPACE allows for concentrated 'headsdown' work lthinking, reading, writing), deep work, and reflection requires reduced stimulation to avoid distraction.

\section{COLLABORATION SPACE} is used for group work, workshops, face-to-face discussions, client meetings, or studentteacher consultations.

\section{PRESENTATION SPACE}

is used to share, present, and consume knowledge, ideas, and work results in a one-directional way (presentations or exhibitions)

\section{MAKING SPACE}

is used for model making and building; allows experimentation, play, noise, and dirt.

\section{INTERMISSION SPACE}

connects other space types; is used for breaks, recreation, and transfers; includes hallways, stairs, cafeterias, and outdoor areas.

\section{SPATIAL QUALITY}

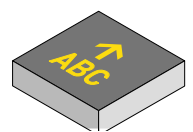

A: KNOWLEDGE PROCESSOR space can store, display, and foster the transfer of information and knowledge (tacit, explicit, and embedded knowledge).

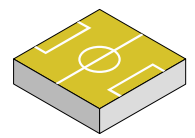

B: INDICATOR OF CULTURE space suggests a specific behavior, either through common sense, written or unwritten rules, rituals, labels, and signs.

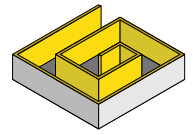

C: PROCESS ENABLER space can provide specific spatial structures or technical infrastructure that might guide or hinder the work process.

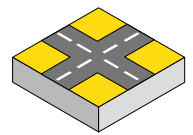

D: SOCIAL DIMENSION space influences social interactions and facilitates meetings and personal exchanges.

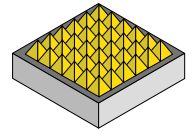

E: SOURCE OF STIMULATION space can provide certain stimuli (views, sounds, smells, textures materials, etc.).

Figure 2. Typology of creative spaces (Thoring et al., in press) 
The entire process was conducted by two researchers, who independently mapped and categorized the data. Steps 4 and 5 were conducted iteratively in order to cover the largest amount of solutions possible, until a theoretical saturation emerged. The resulting insights constitute the nucleus of a pattern language, which is summarized in a total of 49 design principles that are discussed in the next section.

\section{Table 1. Requirements matrix of space types related to spatial qualities}

\begin{tabular}{|c|c|c|c|c|c|}
\hline & $\begin{array}{l}\text { Knowledge } \\
\text { Processor }\end{array}$ & $\begin{array}{l}\text { Indicator of } \\
\text { Culture }\end{array}$ & $\begin{array}{l}\text { Process } \\
\text { Enabler }\end{array}$ & $\begin{array}{l}\text { Social } \\
\text { Dimension }\end{array}$ & $\begin{array}{l}\text { Source of } \\
\text { Stimulation }\end{array}$ \\
\hline $\begin{array}{l}\text { Personal } \\
\text { Space } \\
\text { should/might: }\end{array}$ & $\begin{array}{l}\text { - protect } \\
\text { knowledge } \\
\text { - provide access } \\
\text { to explicit } \\
\text { knowledge } \\
\text { - provide } \\
\text { repository }\end{array}$ & $\begin{array}{l}\text { - indicate privacy } \\
\text { - provide } \\
\text { separation } \\
\text { from others } \\
\text { - express } \\
\text { individuality }\end{array}$ & $\begin{array}{l}\text { - provide secluded } \\
\text { booths } \\
\text { - provide } \\
\text { appropriate } \\
\text { equipment }\end{array}$ & $\begin{array}{l}\text { - reduce } \\
\text { social } \\
\text { interactions }\end{array}$ & $\begin{array}{l}\text { - be protected } \\
\text { from external } \\
\text { stimulation } \\
\text { - provide } \\
\text { individually } \\
\text { adjustable } \\
\text { stimulation }\end{array}$ \\
\hline $\begin{array}{l}\text { Collaboratio } \\
\text { n Space } \\
\text { should/might: }\end{array}$ & $\begin{array}{l}\text { - provide access } \\
\text { to knowledge } \\
\text { - display explicit } \\
\text { knowledge } \\
\text { - enable tacit } \\
\text { knowledge } \\
\text { exchange }\end{array}$ & $\begin{array}{l}\text { - indicate rules for } \\
\text { usage and } \\
\text { behaviour } \\
\text { - be accessible } \\
\text { - be playful } \\
\text { - facilitate } \\
\text { common rituals }\end{array}$ & $\begin{array}{l}\text { - facilitate } \\
\text { teamwork } \\
\text { - provide } \\
\text { collaboration } \\
\text { furniture } \\
\text { - include } \\
\text { flexible and } \\
\text { moveable } \\
\text { furniture }\end{array}$ & $\begin{array}{l}\text { - invite and } \\
\text { enable } \\
\text { social } \\
\text { interaction } \\
\text { - provide } \\
\text { meeting } \\
\text { areas }\end{array}$ & $\begin{array}{l}\text { - provide visual } \\
\text { and acoustic } \\
\text { stimulation } \\
\text { - allow higher } \\
\text { noise level } \\
\text { - limit noise level } \\
\text { to acceptable } \\
\text { degree }\end{array}$ \\
\hline $\begin{array}{l}\text { Making } \\
\text { Space } \\
\text { should/might: }\end{array}$ & $\begin{array}{l}\text { - provide } \\
\text { instructions for } \\
\text { usage } \\
\text { - display artefact } \\
\text { knowledge }\end{array}$ & $\begin{array}{l}\text { - invite } \\
\text { experimentation } \\
\text { - invite trial-and- } \\
\text { error } \\
\text { - allow noise and } \\
\text { dirt }\end{array}$ & $\begin{array}{l}\text { - provide } \\
\text { materials } \\
\text { - provide } \\
\text { making } \\
\text { infrastructure }\end{array}$ & $\begin{array}{l}\text { - facilitate } \\
\text { task-related } \\
\text { social } \\
\text { interactions }\end{array}$ & $\begin{array}{l}\text { - allow higher } \\
\text { noise/dirt level } \\
\text { - limit noise/dirt } \\
\text { to acceptable } \\
\text { degree }\end{array}$ \\
\hline $\begin{array}{l}\text { Presentation } \\
\text { Space } \\
\text { should/might: }\end{array}$ & $\begin{array}{l}\text { - facilitate } \\
\text { knowledge } \\
\text { transfer } \\
\text { - display artefact } \\
\text { knowledge }\end{array}$ & $\begin{array}{l}\text { - upvalue/highlight } \\
\text { presenter or work } \\
\text { - enable/encourage } \\
\text { feedback }\end{array}$ & $\begin{array}{l}\text { - provide } \\
\text { infrastructure } \\
\text { for presenting } \\
\text { - provide a } \\
\text { platform to } \\
\text { display/present } \\
\text { work }\end{array}$ & $\begin{array}{l}\text { - invite } \\
\text { feedback/ } \\
\text { discussions }\end{array}$ & $\begin{array}{l}\text { - reduce external } \\
\text { distraction } \\
\text { - presentation } \\
\text { should become } \\
\text { main } \\
\text { stimulation }\end{array}$ \\
\hline $\begin{array}{l}\text { Intermission } \\
\text { Space } \\
\text { should/might: }\end{array}$ & $\begin{array}{l}\text { - facilitate } \\
\text { knowledge } \\
\text { transfer } \\
\text { - display } \\
\text { knowledge of } \\
\text { general interest } \\
\text { - provide access } \\
\text { to field/user } \\
\text { research }\end{array}$ & $\begin{array}{l}\text { - be inviting, cosy, } \\
\text { welcoming, or } \\
\text { representative } \\
\text { - facilitate } \\
\text { common rituals }\end{array}$ & $\begin{array}{l}\text { - provide outdoor } \\
\text { access } \\
\text { - provide } \\
\text { recreation area } \\
\text { - provide access to } \\
\text { suppliers } \\
\text { - be in proximity } \\
\text { to other spaces }\end{array}$ & $\begin{array}{l}\text { - facilitate } \\
\text { coincidental } \\
\text { meetings } \\
\text { - enable } \\
\text { collective } \\
\text { breaks }\end{array}$ & $\begin{array}{l}\text { - provide fresh air } \\
\text { and/or food } \\
\text { - provide reduced } \\
\text { stimulation } \\
\text { - provide natural } \\
\text { stimulation }\end{array}$ \\
\hline
\end{tabular}

\section{Result: Design principles for creative spaces}

\subsection{Structure of the suggested design principles}

The goal of the developed design principles is to provide designers, design educators, architects, and spatial planners with a resource for a systematic design or redesign of a creative workspace. Each 
principle provides insights on spatial problems, abstracted solution principles, and possible solution examples (where applicable). Each principle can be adapted to the specific needs and integrated in the respective context of the user. All 49 developed design principles follow the same structure: (1) a distinguishable name and number (2) a context description, (3) a problem description (4) a solution description, (5) an explanation for the possible working mechanism of the principle, (6) possible disadvantages (where applicable), (7) references to applicable areas of creative spaces, (8) cross links to other related patterns, and (9) exemplary instantiations from selected design educational or practice environments. Where available, also justificatory knowledge from related literature is provided (10).

\subsection{Overview of 49 spatial design principles}

Table 2 outlines the full list of all 49 abstracted design principles for creative spaces. Each principle is given a distinguishable name that already provides some hints about their possible context and goal. The principles are clustered into four categories - similar to Alexander et al.'s Pattern Language (1977) they are ordered from large scale to small scale: (1) Neighbourhood, (2) Architecture, (3) Interior, and (4) Furniture (Figure 1). This way, people can already select principles according to their available resources and scope. The transition between categories is blurred, as some principles might be implemented in more than one category (e.g. a "high seat" could be a piece of furniture or an elevated stage as part of the interior of a space). The detailed principle descriptions include additional information about the working mechanism of the principle as well as concrete examples and references to related literature. Also, cross-links to related principles invite to some kind of 'browsing' through the list of patterns.

Table 2. Overview of $\mathbf{4 9}$ design principles for creative spaces

Overview of Design Principles (from large scale to small scale)

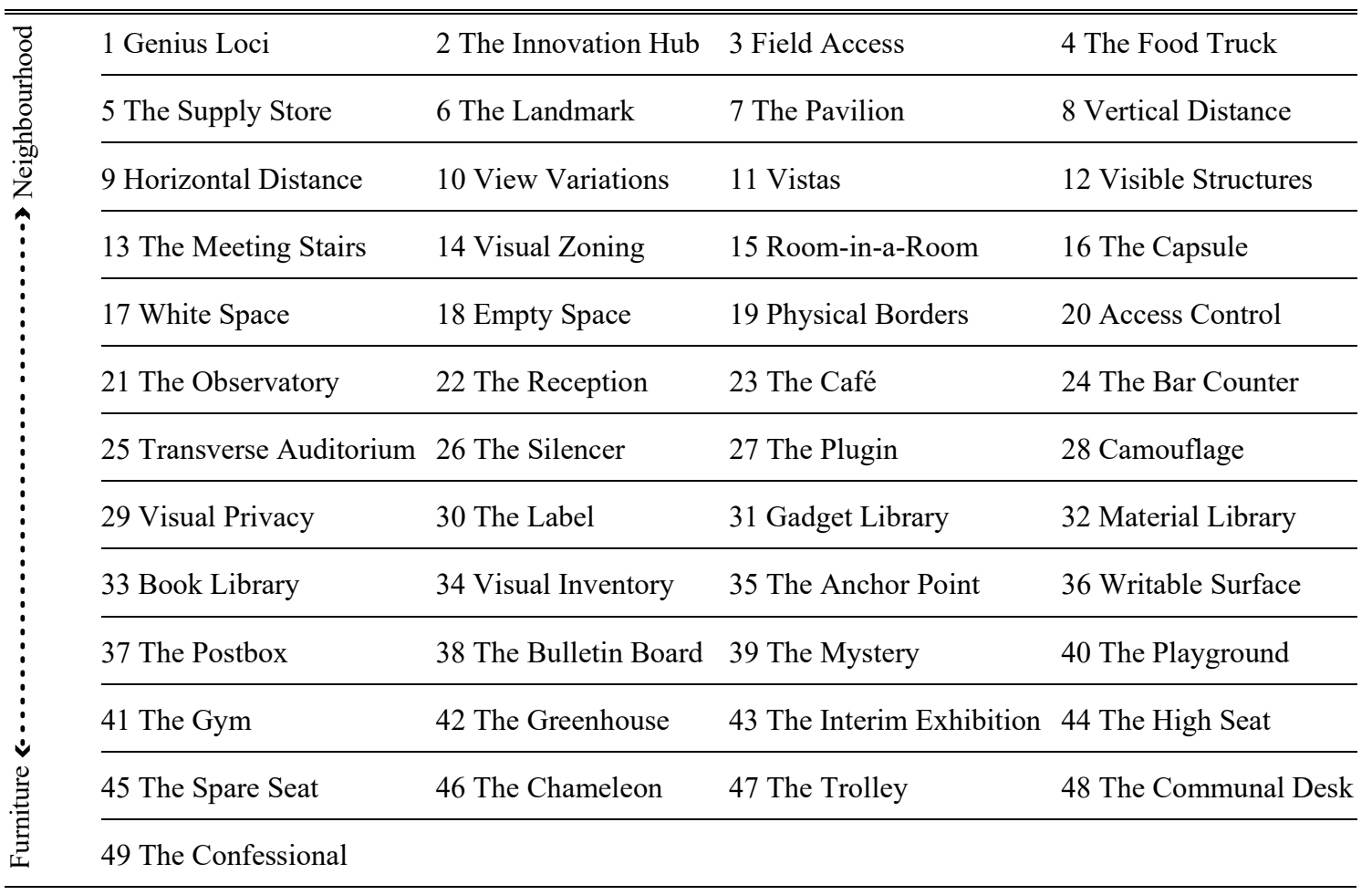

\subsection{Exemplary Principles}

Page limit prevents us from presenting all of the 49 developed design patterns for creative spaces. Hence, in the following we describe only four patterns in detail. 
Table 3. Design principle $N^{\circ} 1$ : Genius Loci (neighbourhood)

\begin{tabular}{|c|c|}
\hline No. 1 & Genius Loci \\
\hline Context & $\begin{array}{l}\text { When looking for a site to establish a creative business or design school (either renting existing premises } \\
\text { or building a new one), location is crucial, because it is difficult or impossible to change afterwards. }\end{array}$ \\
\hline Problem & $\begin{array}{l}\text { Lack of creative and inspiring spirit in an environment might lead to a lack of motivation and } \\
\text { awareness of employees or students. }\end{array}$ \\
\hline Solution & $\begin{array}{l}\text { Choose a location near to or within any neighbourhood that inherits a desired historical or cultural } \\
\text { spirit that one wants to transfer to one's own institution. }\end{array}$ \\
\hline Explanation & $\begin{array}{l}\text { Working or studying within an environment that is historically well-known for creativity and } \\
\text { innovation can result in associative (context) priming of students or employees towards a creative } \\
\text { mind-set and also increase creative motivation. Also, this 'genius loci' might be able to attract other } \\
\text { people to move there, which might raise the level of creative spirit as such. }\end{array}$ \\
\hline Disadvantage & $\begin{array}{l}\text { The presence of historic creative ideas might lead to fixation. } \\
\text { Possibly difficult to realize. }\end{array}$ \\
\hline Addresses & $\begin{array}{l}\text { Space Type: Intermission Space, might affect all other space types } \\
\text { Spatial Quality: Culture }\end{array}$ \\
\hline Cross Link & 2: Innovation Hub, 30: The Label \\
\hline Example & $\begin{array}{l}\text { The Dessau School of Design is located in direct proximity to the German Bauhaus. The presence of the } \\
\text { historic provenance of the design discipline might positively affect students' creative mood and motivation. }\end{array}$ \\
\hline Literature & $\begin{array}{l}\text { Priming: "Understanding Priming Effects in Social Psychology" (Molden, 2014) } \\
\text { Priming: "The state, not the trait, of nostalgia increases creativity" (Ye et al., 2013) } \\
\text { Motivation: "Motivation and Creativity" (Collins and Amabile, 1998) } \\
\text { Motivation: "Enhancing Creativity" (Nickerson, 1998, p. 411) } \\
\text { Fixation: "Design Fixation" (Jansson and Smith, 1991) }\end{array}$ \\
\hline No. 36 & Writeable Surface \\
\hline Context & $\begin{array}{l}\text { Joint teamwork with sketching and note taking; Chatting with colleagues during a break; Getting a } \\
\text { phone call when you are not at your desk. }\end{array}$ \\
\hline Problem & Lack of appropriate equipment for spontaneous or deliberate note taking, idea generation, or sketching. \\
\hline Solution & Integrate paper note pads, whiteboards, or other writeable surfaces into furniture. \\
\hline Explanation & $\begin{array}{l}\text { Allows externalization of tacit knowledge (thoughts and ideas). } \\
\text { Provides a physical platform for ideas. } \\
\text { Sometimes ideas emerge during breaks or intermission, when no equipment is present. } \\
\text { Knowledge remains visible and accessible to other team members. }\end{array}$ \\
\hline Disadvantage & $\begin{array}{l}\text { Retention of ideas might be problematic (archiving paper sheets; pictures of whiteboards). } \\
\text { Writeable whiteboard or chalkboard surface on tables can easily smudge. }\end{array}$ \\
\hline Addresses & $\begin{array}{l}\text { Space Type: Intermission Space, Presentation Space, Collaboration Space } \\
\text { Spatial Quality: Process Enabler, Knowledge Processor }\end{array}$ \\
\hline Cross Link & 17: White Space; 37: The Postbox; 30: The Label \\
\hline Example & $\begin{array}{l}\text { The "Campfire Paper Table" by Steelcase provides a pad of round paper sheets integrated into the } \\
\text { round table top. Whiteboards are typical elements of creative spaces, either as a piece of furniture or } \\
\text { as an entire wall. }\end{array}$ \\
\hline Literature & $\begin{array}{l}\text { Externalization: "The Knowledge Creating Company" Nonaka and Takeuchi (1995) } \\
\text { Retention of Ideas: (Simonton, 1998, 1999) }\end{array}$ \\
\hline
\end{tabular}


Table 5. Design principle $N^{\circ}$ 10: View Variations (architecture)

\begin{tabular}{|c|c|}
\hline No. 10 & View Variations \\
\hline Context & Window views are considered positive for creating an inspiring and stimulating atmosphere. \\
\hline Problem & However, always looking at the same scene might also result in boredom. \\
\hline Solution & $\begin{array}{l}\text { Windows arranged in various sizes, angles, and vertical positions provide a multitude of different } \\
\text { views and motifs. }\end{array}$ \\
\hline Explanation & $\begin{array}{l}\text { Surprising views can create inspiring stimuli. Making new connections can lead to flexibility of ideas. } \\
\text { Occurring coincidences can lead to serendipity. }\end{array}$ \\
\hline Disadvantage & Possible distraction \\
\hline Addresses & $\begin{array}{l}\text { Space Type: Intermission Space, Collaboration Space, Personal Space } \\
\text { Spatial Quality: Stimulation }\end{array}$ \\
\hline Cross Link & 11: Vistas, 21: The Observatory \\
\hline Example & $\begin{array}{l}\text { The Entrance Hall at Umeå School of Architecture provides a wall of variously-sized windows that } \\
\text { allow constantly changing views (providing peeks into the sky as well as to the ground); presenting } \\
\text { the viewer with motifs such as stray dogs, passers-by, flying birds, etc. }\end{array}$ \\
\hline Literature & $\begin{array}{l}\text { Surprise: "From Positive Affect to Creativity" Filipowicz (2006) } \\
\text { Serendipity: "Ubiquitous Serendipity" (Goldschmidt, 2015) }\end{array}$ \\
\hline No. 44 & High Seat \\
\hline Context & $\begin{array}{l}\text { When working in intermission spaces like hallways, people might enjoy casual chats with passers- } \\
\text { by, chance-encounters, or communication with co-workers/classmates. }\end{array}$ \\
\hline Problem & $\begin{array}{l}\text { Seating at normal seating level results in an inconvenient positioning when communicating with } \\
\text { people who are standing or passing-by. }\end{array}$ \\
\hline Solution & Seating area on elevated platform (interior); high-seating stools with high tables (furniture) \\
\hline Explanation & $\begin{array}{l}\text { Raising the eye-level of a seated person by approximately } 40 \mathrm{~cm} \text { will bring him/her in convenient } \\
\text { eye-contact with people who are standing (e.g. passers-by). }\end{array}$ \\
\hline Disadvantage & Possible distraction \\
\hline Addresses & $\begin{array}{l}\text { Space Type: Intermission Space, Collaboration Space } \\
\text { Spatial Quality: Social Interaction }\end{array}$ \\
\hline Cross Link & 11: Vistas, 21: The Observatory, 24: The Bar Counter, 48: Communal Desks, 45: The Spare Seat \\
\hline Example & $\begin{array}{l}\text { Tampere University Finland redesigned their entrance hall by installing several platforms of } \\
\text { different height each (ground level, }+40 \mathrm{~cm} \text {, and }+60 \mathrm{~cm} \text { ). Each platform is equipped with } \\
\text { comfortable seating furniture. }\end{array}$ \\
\hline Literature & Case Study: “A Social Learning Place in Higher Education” Poutanen (2013) \\
\hline
\end{tabular}

These four examples illustrate the potential of the entire set of the 49 spatial design principles. Designers, educators, or spatial planners can use them to identify any similar context or problems within their own environments and adapt the suggested solution principles accordingly. Table 7 outlines the mapping of the 49 developed spatial principles to the typology of creative spaces (see Figure 2 and Table 1). Each cell of the matrix provides the numbers of the related design principles that could be used to address the respective spatial quality of the particular space type. That way, 
people who want to design or redesign their spaces could refer to this table and identify the relevant criteria they want to change, along with the related spatial design principles, indicated by the respective number.

Table 7. Mapping of spatial design principles to the typology of creative spaces

\begin{tabular}{|c|c|c|c|c|c|}
\hline & $\begin{array}{l}\text { Knowledge } \\
\text { Processor }\end{array}$ & $\begin{array}{l}\text { Indicator of } \\
\text { Culture }\end{array}$ & $\begin{array}{l}\text { Process } \\
\text { Enabler }\end{array}$ & $\begin{array}{l}\text { Social } \\
\text { Dimension }\end{array}$ & $\begin{array}{l}\text { Source of } \\
\text { Stimulation }\end{array}$ \\
\hline Personal Space & $\begin{array}{l}20,21,28,31, \\
33,45\end{array}$ & $\begin{array}{l}14,18,19,20 \\
28,29,45,49\end{array}$ & $\begin{array}{l}7,16,26,27 \\
46\end{array}$ & $\begin{array}{l}15,16,28,29 \\
45,49\end{array}$ & $\begin{array}{l}7,10,11,17, \\
18,19,21,26, \\
28,29,33,34, \\
41,42\end{array}$ \\
\hline Collaboration Space & $\begin{array}{l}20,21,28,30 \\
31,33,36,37 \\
38,45,48,49\end{array}$ & $\begin{array}{l}2,14,17,18,19, \\
20,22,23,28, \\
29,30,31,33, \\
35,36,40,41, \\
42,45,48,49\end{array}$ & $\begin{array}{l}7,9,26,27 \\
36,37,44,45 \\
46,47,49\end{array}$ & $\begin{array}{l}11,15,16,23 \\
35,40,44,45 \\
48,49\end{array}$ & $\begin{array}{l}7,10,11,18, \\
19,21,23,26, \\
31,34,40,41, \\
42,43\end{array}$ \\
\hline Making Space & $\begin{array}{l}12,21,30,32, \\
34,43\end{array}$ & $30,32,34$ & $8,27,34,46$ & $5,9,45,49$ & $\begin{array}{l}17,18,19,21 \\
26,32,34\end{array}$ \\
\hline Presentation Space & $\begin{array}{l}21,25,36,37, \\
43\end{array}$ & 6,30 & $\begin{array}{l}25,27,37,46, \\
47\end{array}$ & 24,25 & $\begin{array}{l}21,26,34,39 \\
43\end{array}$ \\
\hline Intermission Space & $\begin{array}{l}2,3,21,24,33, \\
36,43\end{array}$ & $\begin{array}{l}1,2,6,14,22 \\
33,40,41,42,49\end{array}$ & $\begin{array}{l}3,5,9,24,27 \\
36,44,46,47\end{array}$ & $\begin{array}{l}3,4,8,9,11, \\
13,15,16,22, \\
23,24,35,40, \\
41,44,45,48, \\
49\end{array}$ & $\begin{array}{l}4,5,10,11,17, \\
21,23,26,33, \\
34,39,40,41, \\
42,43\end{array}$ \\
\hline
\end{tabular}

\section{Discussion}

\subsection{Contribution}

The presented design principles constitute a novel method for designing creative spaces. They provide the users not only with inspirations for their own spatial designs but also references to related studies with empirical data to substantiate any design decision. Furthermore, the paper adds to the existing research on creative spaces by providing a structured schema for spatial analyses, as well as by suggesting a variety of design possibilities.

\subsection{Implications}

The 49 principles presented in this paper suggest abstracted guidelines for designing creative spaces in terms of furniture solutions, room layouts and interiors, the architecture, and the neighbourhood within the campus or the city. We tried to find an appropriate level of abstraction that reduces the number of principles to a minimum and avoids redundancy, but at the same time leaves the users enough flexibility to adapt the principles to their own context and requirements. In that way, the principles could be used to design or redesign spaces in design education or design practice, but also in other creative areas, such as maker or hacker spaces, or even spaces for music and fine arts. Although the latter would most certainly require different instantiations of a space (in terms of infrastructure), the general requirements for creative environments remain comparable and can be addressed through the abstracted principles. The presented design principles constitute the theoretical groundwork for a 'pattern language for creative spaces', that still needs to be transferred into a tangible tool. We envision a card set that could be used threefold: (1) as an inspirational resource that one can browse in order to find inspirations for their own creative environments, (2) as some sort of analysis tool that one could apply in an existing environment 
to identify areas needing improvement, and (3) as a practical tool to identify solutions for specificalready known - spatial problems, by referring to the context and problem descriptions of each principle.

\subsection{Constraints}

It lies in the nature of these design principles that some are easier to implement than others. For example, the suggested principles addressing the neighbourhood can only be realized when one is searching for a new location to rent or build, while the architectural principles might require some fundamental construction measures, such as tearing down walls, or building from scratch. In contrast, the principles in the interior and furniture category are easier to implement and most can be realized with just a few layout or design modifications or by buying or building some pieces of new furniture.

\section{Conclusions}

In this paper, we present a set of design principles that form a preliminary 'pattern language' of creative spaces. Based on a typology of creative spaces (Thoring et al., in press) and an inductive approach with eight expert interviews and case studies in 16 institutions, we developed a set of 49 design principles that can be adapted by the users to create design environments. The suggested principles provide insights into working mechanisms for facilitating design activities and improving design processes through the spatial environment. They are not meant to provide exact design blueprints but rather exemplary concepts, which need to be adapted by the designers or spatial planners to match their own contexts and requirements. Our principles for creative spaces provide the users with the required context information, what kind of spatial configuration would be appropriate for the given situation. Although the collection of design principles was developed with the peculiar requirements of design education and practice in mind, we are certain that several of the suggested guidelines are adaptable for other disciplines and environments. However, further research is needed to investigate and validate this assumption.

The next step for finalising the pattern language of creative spaces will result in a tangible and manageable form that can be used by designers and spatial planners. For this purpose, we will consolidate all principles in a card set, each card representing one principle and an exemplary picture of found instantiations of creative spaces. We are planning to conduct several spatial planning workshops in different contexts in order to test the applicability of the developed principles. Specifically, we want to validate the principles' usefulness (a) to analyse existing spaces, and (b) to facilitate the design of a new creative environment. Some of the presented principles might raise some contradictions - where improving one aspect results in a worsening of another aspect. For example, an open space concept with lots of vistas allows for personal exchange and inspiring views (positive), but at the same time it raises the noise level and the risk of distraction (negative). This situation bears resemblance to the concept of TRIZ - a problem solving technique that was developed by Genrich Altshuller in the 1940s (Altshuller et al., 1997). While TRIZ provides a list of possible solution principles to technical contradictions, our goal is to adapt the approach to spatial design problems. A first step for defining such contradictions is already outlined in the 'disadvantage' section of each principle. In future work we want to elaborate on such emerging contradictions and develop the design principles for creative spaces further into a "Spatial TRIZ" application. We based the development of the 49 design principles on an iterative procedure of empirical and literature-based research until a theoretical saturation emerged. Future work will include validation studies and extensions of the principles, where needed.

\section{References}

Alexander, C., Ishikawa, S. and Silverstein, M. (1977), A pattern language: towns, buildings, construction, Oxford University Press, New York, USA.

Altshuller, G., Shulyak, L. and Rodman, S. (1997), 40 principles: TRIZ keys to innovation, Technical Innovation Center, Worcester MA.

Borges, S., Ehmann, S. and Klanten, R. (2013), Work scape new spaces for new work, Gestalten, Berlin. 
Ceylan, C., Dul, J. and Aytac, S. (2008) “Can the office environment stimulate a manager's creativity?”, Human Factors and Ergonomics in Manufacturing and Service Industries, Vol. 18 No. 6, pp. 589-602. https://doi.org/10.1002/hfm.20128

Collins, M.A. and Amabile, T.M. (1998), "Motivation and Creativity", In: Sternberg, R.J. (Ed.), Handbook of Creativity, Cambridge University Press, Cambridge, pp. 297-312. https://doi.org/10.1017/CBO9780511807916.017

Doorley, S. and Witthoft, S. (2012), Make space: how to set the stage for creative collaboration, John Wiley and Sons, Hoboken, N.J.

Dudek, M. (2012). Spaces for young children: A practical guide to planning, designing and building the perfect space, 2nd ed., National Chil Bureau Enterprises, London.

Ehmann, S., Borges, S. and Klanten, R. (2012), Learn for life: New architecture for new learning, Gestalten, Berlin.

Filipowicz, A. (2006), "From Positive Affect to Creativity: The Surprising Role of Surprise", Creativity Research Journal, Vol. 18 No. 2, pp. 141-152. https://doi.org/10.1207/s15326934crj1802_2

Gaver, B., Dunne, T. and Pacenti, E. (1999), "Design: Cultural probes”, Interactions, Vol. 6 No. 1, pp. $21-29$. https://doi.org/10.1145/291224.291235

Georgi, W. and McNamara, C. (2016), The other office: Creative workplace design 2, Frame Publishers, Amsterdam.

Goldschmidt, G. (2015), "Ubiquitous serendipity: Potential visual design stimuli are everywhere”, In: Gero, J. (Ed.), Studying visual and spatial reasoning for design creativity, Springer, Dordrecht, pp. $205-214$. https://doi.org/10.1007/978-94-017-9297-4 12

Gregor, S. (2006), "The nature of theory in information systems”, Management Information Systems, Vol. 30 No. 3, pp. 611-642. https://doi.org/10.2307/25148742

Gregor, S. and Jones, D. (2007), "The anatomy of a design theory", Journal of the Association for Information Systems, Vol. 8 No. 5, pp. 312-335. https://doi.org/10.17705/1jais.00129

Groves, K., Knight, W. and Denison, E. (2010), I wish I worked there! A look inside the most creative spaces in business, Wiley, Hoboken, N.J.

Jansson, D.G. and Smith, S.M. (1991), "Design fixation", Design Studies, Vol. 12 No. 1, pp. 3-11. https://doi.org/10.1016/0142-694X(91)90003-F

Mirchandani, N. (2015), Future schools: Innovative design for existing and new build, Riba, Newcastle.

Molden, D.C. (2014), "Understanding Priming Effects in Social Psychology: What is "Social Priming” and How does it Occur?” Social Cognition, Vol. 32, pp. 1-11. https://doi.org/10.1521/soco.2014.32.supp.1

Nickerson, R.S. (1998), "Enhancing Creativity", In: Sternberg, R.J. (Ed.), Handbook of Creativity, Cambridge University Press, Cambridge, pp. 392-430. https://doi.org/10.1017/CBO9780511807916.022

Nonaka, I. and Takeuchi, H. (1995), The knowledge-creating company: How Japanese companies create the dynamics of innovation, Oxford University Press, USA.

Paoli, D.D., Sauer, E. and Ropo, A. (2017), "The spatial context of organizations: A critique of "creative workspaces"”, Journal of Management and Organization, pp. 1-22. https://doi.org/10.1017/jmo.2017.46

Popper, K.R. (1934), Logik der Forschung, Springer, Wien.

Poutanen, J. (2013), “A Designed Third Place as Social Learning Space in Higher Education - Case Motivaattori”, INTED2013 Proceedings, pp. 688-697.

Simonton, D.K. (1998), "Donald Campbell's model of the creative process: Creativity as blind variation and selective retention", Journal of Creative Behavior, Vol. 32, pp. 153-158. https://doi.org/10.1002/j.21626057.1998.tb00812.x

Simonton, D.K. (1999), Origins of genius: Darwinian perspectives on creativity, Oxford, New York.

Snead, L. and Wycoff, J. (1999), "Stimulating innovation with collaboration rooms", Journal for Quality and Participation, Vol. 22 No. 2, pp. 55-57.

Stewart, M. (2004), The other office: Creative workplace design, Birkhäuser, Boston.

Thoring, K., Desmet, P. and Badke-Schaub, P. (in press), "Creative environments for design education and practice: a typology of creative spaces”, Design Studies. 
Thoring, K., Gonçalves, M., Mueller, R.M., Badke-Schaub, P. and Desmet, P. (2017), "Inspiration Space: Towards a theory of creativity-supporting learning environments", Proceedings of the Design Management Academy (DMA), Hong Kong, CN, pp. 1539 - 1561. https://doi.org/10.21606/dma.2017.19

Thoring, K., Luippold, C. and Mueller, R.M. (2012). “Creative Space In Design Education: A Typology of Spatial Functions", Proceedings of the International Conference on Engineering and Product Design Education, Antwerp, Belgium.

Williams, A. (2013), A grammar of creative workplaces, PhD thesis, University of East London, London, UK.

Ye, S., Ngan, R.Y.L. and Hui, A.N. (2013), "The state, not the trait, of nostalgia increases creativity", Creativity Research Journal, Vol. 25 No. 3, pp. 317-323. https://doi.org/10.1080/10400419.2013.813797

Yin, R.K. (2003), Case study research: design and methods, Sage Publications, Thousand Oaks, California.

Katja Thoring, Prof.

Delft University of Technology, Industrial Design

Landbergstraat, 2628 CE Delft, Netherlands

Email: k.c.thoring@tudelft.nl 